\title{
Sol-gel niobium pentoxide coatings: Applications to photovoltaic energy conversion and electrochromism
}

\author{
Michel A. Aegerter, ${ }^{1, \dagger}$ Michael Schmitt, ${ }^{2, \ddagger}$ and Yeping Guo ${ }^{1}$ \\ ${ }^{1}$ Institut für Neue Materialien, INM, Department of Coating Technology, Gebaeude 43, 66123 Saarbruecken, Germany \\ ${ }^{2}$ DIN, Deutsches Institut für Normung e.V., Normenausschuss Materialpruefung (NMP), Burggrafenstraße 6, D-10787 Berlin
}

\begin{abstract}
In the last decade the sol-gel process became a promising method to synthesize materials in form of coatings, nanoscale powders and porous systems. Several products or devices made with such a process already exist on the market. This paper briefly reviews the state of the art in the development of electrochromic coatings and devices and nanocrystalline solar cells achieved during the last decade using sol-gel derived pure and doped niobium pentoxide.
\end{abstract}

\section{INTRODUCTION}

Stoichiometric niobium oxides mainly exist in the form of $\mathrm{NbO}, \mathrm{Nb}_{2} \mathrm{O}_{3}, \mathrm{NbO}_{2}$ and $\alpha, \beta \mathrm{Nb}_{2} \mathrm{O}_{5}$ [1]. Niobium pentoxide is however the most studied material. It has been prepared by different methods such as oxidation of metallic niobium in air, by hydrolyzing alkali-metal niobates, niobium alkoxides and niobium pentachloride or by precipitation from solution in hydrofluoric acid with alkali-metal hydroxide or ammonia [2]. $\mathrm{Nb}_{2} \mathrm{O}_{5}$ possesses a quite complex crystalline morphology. The phases most often found have been labeled T, TT, B, $\mathrm{M}$ and $\mathrm{H}[3,4]$ and their appearance depends on the preparation method of the compound and the kinetics and thermodynamics. The $\mathrm{T}$ and TT phases are essentially observed below $800{ }^{\circ} \mathrm{C}$ and the TT phase, indexed as pseudohexagonal, is thought to be a modification of the orthorhombic T phase as it presents a lower crystallinity and is probably stabilized by impurities such as $\mathrm{OH}^{-}, \mathrm{Cl}^{-}$or vacancies [5]. Stoichiometric $\mathrm{Nb}_{2} \mathrm{O}_{5}$ is an insulator [1], but it becomes a $n$-type semiconductor at lower oxygen content.

Traditionally niobium pentoxide is used in metallurgy for the production of hard materials or in optics as additive to prevent the devitrification and to control the refractive index of special glasses. In electronics it is used for the preparation of electroacoustic or electrooptical components such as $\mathrm{LiNbO}_{3}$ and $\mathrm{KNbO}_{3}$ or relaxor ferroelectric ceramics such as $\mathrm{Pb}\left(\mathrm{Mg}_{1 / 3} \mathrm{Nb}_{2 / 3}\right) \mathrm{O}_{3}$ [2]. However, in the last 15 years, its interesting semiconducting properties and the advent of more sophisticated methods of preparation allowed the obtaining in a controlled way of innovative systems such as highly porous materials, very fine powders and coatings. These new materials have found further

\footnotetext{
†E-mail: aegerter@inm-gmbh.de
}

‡E-mail: michael.schmitt@din.de important application in the field of electrochromism, batteries, solar cells and catalysis [6].

This paper summarizes the recent results obtained in the field of electrochromism (Section 2) and nanocrystalline solar cells, the so-called Graetzel cells (Section 3) with pure and doped niobium pentoxide prepared by the sol-gel process, although some references are also given for comparison for other preparation routes. A conclusion follows in Section 4.

\section{2. $\mathrm{Nb}_{2} \mathrm{O}_{5}$ ELECTROCHROMIC (EC) COATINGS AND DEVICES}

General reviews on the preparation and on the properties of electrochromic coatings and devices prepared by the sol-gel method have been already published by Agrawal et al. [7] and the author [8-10].

The first mention of a persistent but reversible optical change produced electrochemically in $\mathrm{Nb}_{2} \mathrm{O}_{5}$ coatings was published by Reichman and Bard in 1980 [11]. Such an effect was observed on a niobium metallic disk oxidized at approximately $500{ }^{\circ} \mathrm{C}$ for $10 \mathrm{~min}$. The blue coloring effect, seen in reflection under $\mathrm{H}^{+}$and later also under $\mathrm{Li}^{+}$insertion [12], was chemically stable and showed fast kinetics (1 to $2 \mathrm{~s}$ ).

Since then several more adequate deposition techniques have been used to obtain niobium oxide EC films among which CVD [13], DC magnetron sputtering [14], electrochemical method [15] and the dip or spin coating process via the sol-gel route [6].

2.1. Pure niobium oxide sol-gel coatings and devices. Lee and Crayston [16] were the first to show that pure sol-gel $\mathrm{Nb}_{2} \mathrm{O}_{5}$ coatings present an electrochromic effect. They prepared 5 to $10 \mu \mathrm{m}$ thick coatings by spinning a hydrolyzed solution of $\mathrm{NbCl}_{5}$ dissolved in ethanol on ITO coated glass. The films showed 
a blue coloration with fast coloration (approx. $6 \mathrm{~s}$ ) and bleaching (approx. $3 \mathrm{~s}$ ) kinetics and a coloration efficiency of $6 \mathrm{~cm}^{2} / \mathrm{C}$ but the durability of the EC response was only a few cycles.

Since then many sol compositions and preparation routes have been tested and an analysis of the published reports [6] shows that the best niobium oxide coatings for EC purpose prepared by the sol-gel process are those made from alkoxides or chloroalkoxides based sols. The choice of the precursor does not seem to have a large influence on the final EC properties. However, according to Schmitt et al. [17, 18], the amount of lithium ions which can be inserted reversibly into the films as well as the corresponding change of the optical density both decrease with increasing length of the alkyl chain. Therefore ethanol is the preferred solvent for the sol preparation. Large indium tin oxide (ITO) or fluorine doped tin oxide (FTO) coated glass substrates can thus be coated by the dip coating process at a withdrawal rate of typically $2 \mathrm{~mm} / \mathrm{s}$. Depending on the sol concentration the thickness of the resulting films varies between 30 and $140 \mathrm{~nm}$ and the coating procedure has to be repeated several times to obtain thick coatings, each layer being previously dried and partly sintered at $400{ }^{\circ} \mathrm{C}$ before the next deposition step. Thick coating stacks can be sintered up to $600^{\circ} \mathrm{C}$, which is the highest temperature allowed to keep the commercial conductive substrates with good electrical properties.

The results presenting here have been obtained with coatings deposited by the dip-coating process using sols obtained by the chloroalkoxide route i.e. by dissolving $\mathrm{NbCl}_{5}$ in ethanol and acetic acid $[17,18]$. Figure 1 shows a typical differential thermal analysis (DTA) and thermogravimetry (TG) of a pure $\mathrm{Nb}_{2} \mathrm{O}_{5}$ xerogel dried at $100^{\circ} \mathrm{C}$. An endothermic peak is first observed at about $200^{\circ} \mathrm{C}$ followed by an exothermic peak at $250{ }^{\circ} \mathrm{C}$. Both peaks are accompanied by a $9 \%$ mass loss due essentially to the evolution of the solvent molecules (fraction

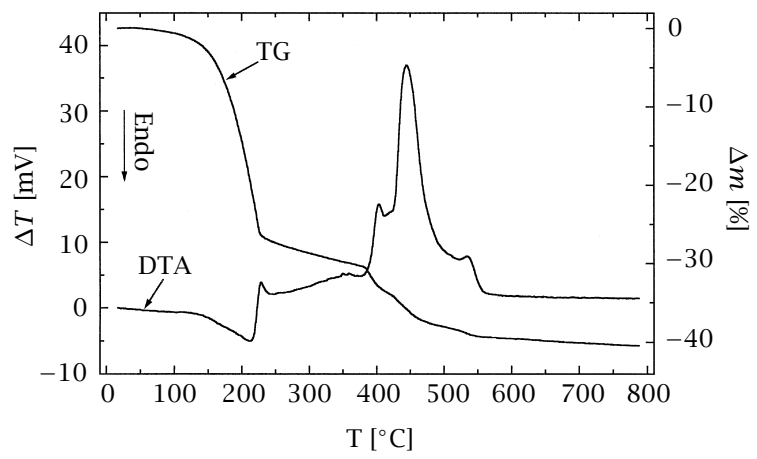

Figure 1. DTA and TG curves measured at $10 \mathrm{~K} / \mathrm{min}$ of a $\mathrm{Nb}_{2} \mathrm{O}_{5}$ xerogel dried at $100{ }^{\circ} \mathrm{C}$ prepared by the chloroalkoxide route [17, 18]. of the type $\mathrm{C}_{x} \mathrm{H}_{y}$ (mass 26, 27, 39, 42, 43, 55, 66, 57) and to a minor extent, the evolution of $\mathrm{HCl}$ (mass 36 and 37) as obtained by a simultaneous mass spectrometry (MS) analysis $[17,18]$. These results are indicative of the building up of an inorganic amorphous network, as confirmed by the X-ray diffractograms (Figure 2).

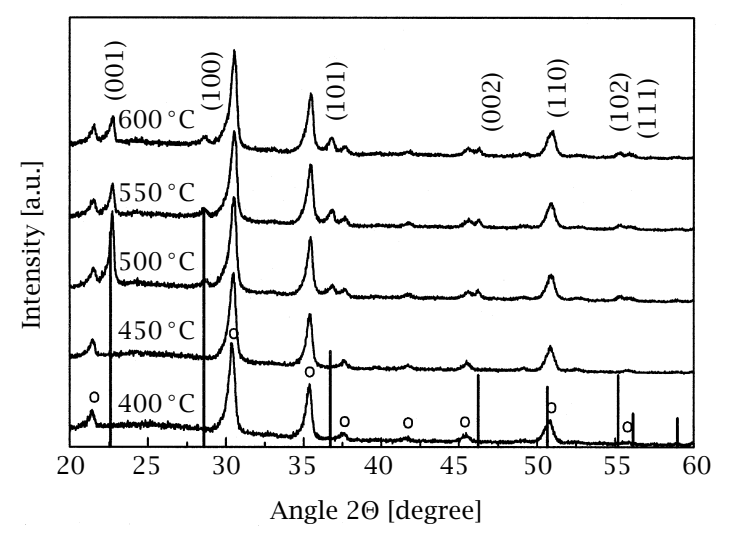

Figure 2. X-ray diffraction of a two layers undoped $\mathrm{Nb}_{2} \mathrm{O}_{5}$ coatings (thickness approx. $120 \mathrm{~nm}$ ) deposited on ITO coated glass sintered between 400 and $600{ }^{\circ} \mathrm{C}$. (0: ITOpeaks. Vertical lines JCPDS 28-317 data (hexagonal structure of $\left.\mathrm{Nb}_{2} \mathrm{O}_{5}\right)$ ) [17, 18].

The second large exothermic double peak at about $470{ }^{\circ} \mathrm{C}$ is accompanied by a smaller mass loss of $2.5 \%$. MS analysis indicates that the loss corresponds essentially to the evolution of $\mathrm{HCl}$ (mass 36 and 37) and to the same fractions of organic molecules as above. The DTA peaks correspond to a crystallization process (Figure 2). A detailed analysis indicates that in the temperature range 460 to $600{ }^{\circ} \mathrm{C}$ the niobium oxide films exhibit the hexagonal structure (TT phase) with crystallite size of about $70 \mathrm{~nm}$. The layers were found to be highly (001) oriented.

The results of electrochemical-optical studies can be classified in three groups depending on the sintering temperature. Typical cyclic voltammetry curves measured at a $50 \mathrm{mV} / \mathrm{s}$ rate between $+1 \mathrm{~V}$ and $-2.2 \mathrm{~V}$ vs. $\mathrm{Ag} / \mathrm{AgClO}_{4}$ during the $50^{\text {th }}$ cycle are given in Figure 3 for amorphous coatings sintered at $450{ }^{\circ} \mathrm{C}$ and for crystalline samples sintered at $500^{\circ} \mathrm{C}$ (low crystallinity) and $600{ }^{\circ} \mathrm{C}$ (high crystallinity). All coatings are approx. $120 \mathrm{~nm}$ thick with a $6.6 \mathrm{~cm}^{2}$ area. The measurements have been done using a 3-electrode optical cell containing a $1 \mathrm{M}$-solution of $\mathrm{LiClO}_{4}$ dissolved in propylene carbonate as electrolyte and a $\mathrm{Ag} / \mathrm{AgClO} 4$ (0.01 M-solution dissolved in the used electrolyte) as reference electrode. For all materials, the reduction of $\mathrm{Nb}^{\mathrm{V}}$ to $\mathrm{Nb}^{\mathrm{IV}}$ occurs below $-1 \mathrm{~V}$ and the peak maximum which lies below $-2.2 \mathrm{~V}$ is not observed. The maximum of the oxidation peak lies at about $-1.2 \mathrm{~V}$ for 


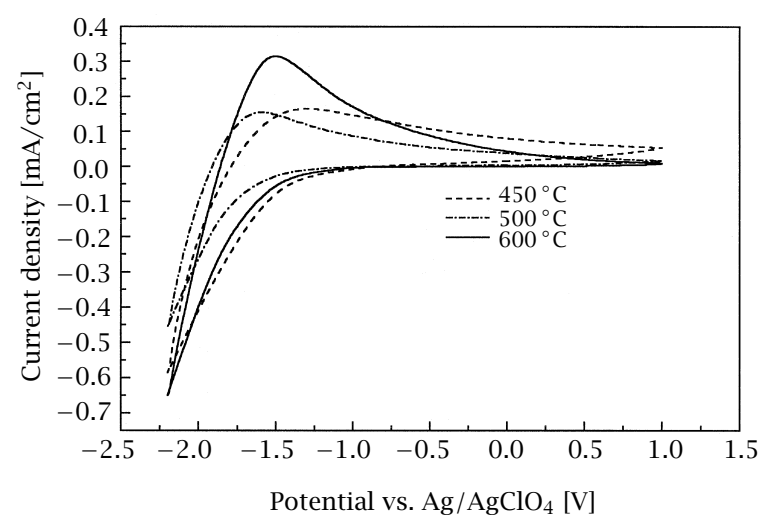

Figure $3.50^{\text {th }}$ cycle voltammetry curves of two layers $\mathrm{Nb}_{2} \mathrm{O}_{5}$ coatings (thickness approx. $120 \mathrm{~nm}$ ) sintered at $450{ }^{\circ} \mathrm{C}$ (amorphous) and 500 and $600^{\circ} \mathrm{C}$ (crystalline) $[17,18]$.

the amorphous phase and is shifted to more negative potentials as the crystallinity increases. The width of the oxidation peak is larger for amorphous coatings indicating slower bleaching kinetics than for crystalline samples. For the crystalline samples the height of the peak increases and shifts to higher potentials with increasing temperature.

Figure 4 shows chronoamperometric curves measured during the $50^{\text {th }}$ cycle for the same samples with voltage of $-2.2 \mathrm{~V}$ and $+1 \mathrm{~V}$ applied during $120 \mathrm{~s}$. Coloration kinetics is always found slower than the bleaching one. For the crystalline samples the kinetics of both coloration and bleaching becomes faster as the sintering temperature increases and reaches practically the same value at $600^{\circ} \mathrm{C}$ as those of the amorphous phase at $450^{\circ} \mathrm{C}$. The diffusion coefficients $D$ for $\mathrm{Li}$ as determined by analyzing the time behavior $I(t) \sim D^{0.5} t^{-0.5}$ [19] are in the range of $10^{-11} \mathrm{~cm}^{2} / \mathrm{s}$ and slightly increase with the sintering temperature.

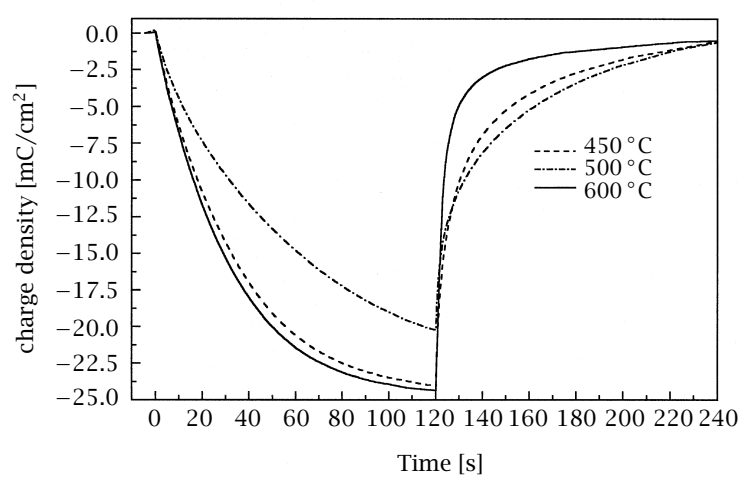

Figure $4.50^{\text {th }}$ chronoamperometric cycle $(-2.2 \mathrm{~V} ;+1.0 \mathrm{~V}$ vs. $\mathrm{Ag} / \mathrm{AgClO}_{4}$ ) of two layers $\mathrm{Nb}_{2} \mathrm{O}_{5}$ coatings (thickness approx. $120 \mathrm{~nm}$ ) sintered at $450^{\circ} \mathrm{C}$ (amorphous) and 500 and $600^{\circ} \mathrm{C}$ (crystalline) $[17,18]$.
Figure 5 shows the spectral dependence of the change of the optical density $\left(\Delta \mathrm{OD}=-\log _{10}\left(T_{\text {bleached }} /\right.\right.$ $\left.T_{\text {colored }}\right)$ of the same samples measured during the $50^{\text {th }}$ chronoamperometric cycle. The spectra are quite different and reflect the fact that the coatings, when seen in transmission, color brown in the amorphous state $\left(T<450{ }^{\circ} \mathrm{C}\right)$ and blue in the crystalline state (TT phase for $T>500^{\circ} \mathrm{C}$ ). For both types of morphology $\Delta \mathrm{OD}$ increases with the sintering temperature reflecting faster kinetics as discussed above (Figure 4).

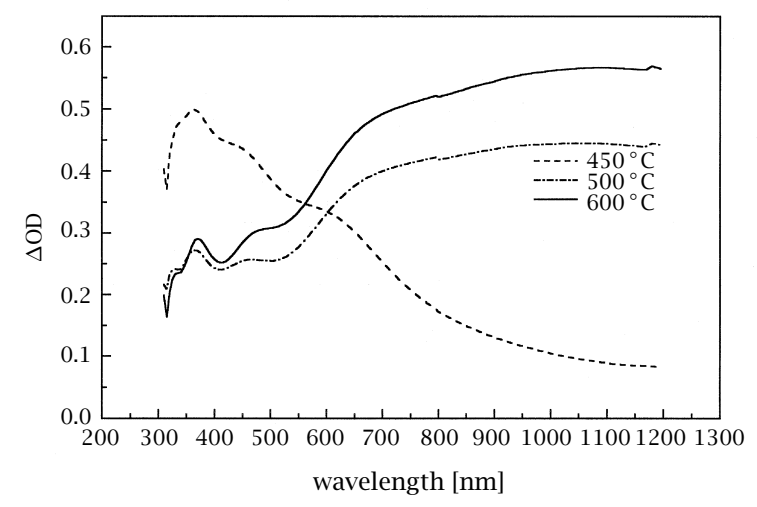

Figure 5. Spectrum of the optical density change $\Delta \mathrm{OD}$ of two layers $\mathrm{Nb}_{2} \mathrm{O}_{5}$ coatings (thickness approx. $120 \mathrm{~nm}$ ) sintered at $450^{\circ} \mathrm{C}$ (amorphous) and 500 and $600^{\circ} \mathrm{C}$ (crystalline) measured during the $50^{\text {th }}$ chronoamperometric cycle $\left(-2.2 \mathrm{~V}, 120 \mathrm{~s} ;+1.0 \mathrm{~V}, 120 \mathrm{~s}\right.$ vs. $\left.\mathrm{Ag} / \mathrm{AgClO}_{4}\right)[17,18]$.

To make practical devices, it is mandatory to know the electrochemical and optical behavior as a function of the number of applied electrochemical cycles. The optical change and amount of $\mathrm{Li}^{+}$charge inserted and extracted have been measured up to 5000 chronoamperometry or voltammetry cycles under the above specifications and found stable with a coloration efficiency of $18.8 \mathrm{~cm}^{2} / \mathrm{C}$ at $550 \mathrm{~nm}$ (amorphous coatings) and that the coloration kinetics become slower and the bleaching one faster as the number of cycles increases. Similar responses were also found with the crystalline coatings sintered between $500{ }^{\circ} \mathrm{C}$ and $600^{\circ} \mathrm{C}$. The layers are also stable up to at least 5000 cycles but the coloration efficiency at $550 \mathrm{~nm}$ is lower, approx. $16 \mathrm{~cm}^{2} / \mathrm{C}$. These values are significantly smaller than the $35 \mathrm{~cm}^{2} / \mathrm{C}$ obtained for films made with $\mathrm{Nb}$ ethoxide but measured under $\mathrm{H}^{+}$insertion at $700 \mathrm{~nm}$ [20] and for sol-gel $\mathrm{WO}_{3}$ layers, the best EC coatings at present, which possess a coloration efficiency of about $50 \mathrm{~cm}^{2} / \mathrm{C}$ after sintering at $220^{\circ} \mathrm{C}$ [21]. It is also worth to mention the value of $35 \mathrm{~cm}^{2} / \mathrm{C}$ obtained by Yoshimura et al. for $\mathrm{Li}^{+}$insertion into a niobia film made by DC magnetron sputtering [14] and the very high coloration efficiency of $160 \mathrm{~cm}^{2} / \mathrm{C}$ measured at $550 \mathrm{~nm}$ in the early stages of coloration by $\mathrm{H}^{+}$insertion by Maruyama 
et al. [13] for an amorphous niobia film made by a CVD process.

The sol-gel made niobium oxide is therefore an interesting candidate to realize solid state EC cells as it results in good coating, offers the possibility to get thick transparent coatings and shows reasonable coloration efficiency and high reversibility and stability under $\mathrm{H}^{+}$or $\mathrm{Li}^{+}$insertion. However, the results have been quite disappointing till today. Avellaneda [22] realized a cell with the configuration glass /ITO $/ \mathrm{Nb}_{2} \mathrm{O}_{5}$ /electrolyte $/ \mathrm{CeO}_{2}-\mathrm{TiO}_{2} / \mathrm{ITO} /$ glass. By switching between +1.5 to $-2.0 \mathrm{~V}$ only a very small Li insertion has been observed, typically $2.5 \mathrm{mC} / \mathrm{cm}^{2}$ but no coloration has been observed. Schmitt [18], using the same configuration with a $125 \mathrm{~nm}$ thick $\mathrm{Nb}_{2} \mathrm{O}_{5}$ and a $240 \mathrm{~nm}$ thick $\mathrm{CeO}_{2}-\mathrm{TiO}_{2}$ counter electrode measured also a very small $\mathrm{Li}$ insertion $\left(<0.25 \mathrm{mC} / \mathrm{cm}^{2}\right.$ after switching between $-2.5 \mathrm{~V}$ and $+1 \mathrm{~V}$ during $120 \mathrm{~s}$ ) with a corresponding change in optical density at $500 \mathrm{~nm}$ lower than 0.01 ! Only Orel et al. [23-25] succeeded to observe a transmission change between $60 \%$ and $33 \%$ using a sol-gel $\mathrm{SnO}_{2}: \mathrm{Sb}(7 \%)$ : Mo10\% layer as counter electrode (IS) switching between $-4.0 \mathrm{~V}($ !) and $+2.0 \mathrm{~V}$ during $120 \mathrm{~s}$. Due to the very high negative applied potential, the cell had a very poor stability, less than 500 cycles. These poor results have been explained by Schmitt et al. [18, 26] using a model originally developed by Bullock and Branz [27] as being due to the too large difference existing between the internal (Fermi) potential of pure $\mathrm{Nb}_{2} \mathrm{O}_{5}$ and the ion-storage electrodes.

\subsection{Doped niobium oxide sol-gel coatings and de-}

vices. Niob(V)oxide has been either used as a doping material for already known electrochromic materials or has been doped with different compounds [6].

For the last case, the most detailed development has been made recently by Schmitt et al. [17, 18] who mixed $\mathrm{NbCl}_{5}$ /ethanol/acetic acid sols with compounds of $\mathrm{Li}$, (incorporated as $\mathrm{LiCF}_{3} \mathrm{SO}_{3}$ or lithium acetate), Ti (as $\left[\left(\mathrm{CH}_{3}\right)_{2} \mathrm{CHO}\right]_{4} \mathrm{Ti}$ ), $\mathrm{Sn}$ (as $\mathrm{SnCl}_{4} \bullet 5 \mathrm{H}_{2} \mathrm{O}$ ), $\mathrm{Zr}$ (as $\mathrm{ZrOCl}_{2} \bullet 8 \mathrm{H}_{2} \mathrm{O}$ ) and $\mathrm{Mo}\left(\right.$ as $\mathrm{H}_{3} \mathrm{Mo}_{12} \mathrm{O}_{40} \mathrm{P} \bullet \mathrm{xH}_{2} \mathrm{O}$ ) to study the influence of the doping on the EC properties of sol-gel coatings sintered between 400 and $600{ }^{\circ} \mathrm{C}$ and devices $[18,26]$. The overall behavior of the DTA/TG curves was found similar to that shown in Figure 1. However, depending on the type and amount of doping, the temperature of the formation of the inorganic amorphous network and of the crystallization processes were slightly different. Except for Mo doping all layers were found amorphous between approx. $250{ }^{\circ} \mathrm{C}$ and $450{ }^{\circ} \mathrm{C}$ and after $\mathrm{Li}^{+}$insertion the color in transmission were brown as for the pure niobium oxide. However, besides the already known TT and T phases leading to a blue coloring effect, other structural phases such as $\mathrm{LiNb}_{3} \mathrm{O}_{8}, \mathrm{Ti}_{2} \mathrm{Nb}_{10} \mathrm{O}_{29}, \mathrm{Nb}_{2} \mathrm{O}_{29}$, etc. have been observed at higher sintering temperature. In their presence the layers colored gray under $\mathrm{Li}^{+}$insertion. A detailed analysis of these results shows that the color of the layers is essentially dependent on the size of the crystallites and not on the crystal structure of the materials.

The three typical spectra observed in this study are shown in Figure 6. A shift of the peak maximum of the spectra as a function of the morphology was also observed for $\mathrm{WO}_{3}$. Amorphous layers have an absorption maximum at $900 \mathrm{~nm}$ while for well crystalline layers the peak lies at $1400 \mathrm{~nm}[28,29]$. However, as both peak maxima are lying in the infrared, the resulting color of both coatings remains blue. The absorption mechanism for the brown amorphous niobia layer is thought to arise from polaron absorption. As the crystalline order increases the absorption band becomes broader and the blue color can probably be explained by the Drude model in which the absorption is essentially governed by interaction with free electrons (high reflection).

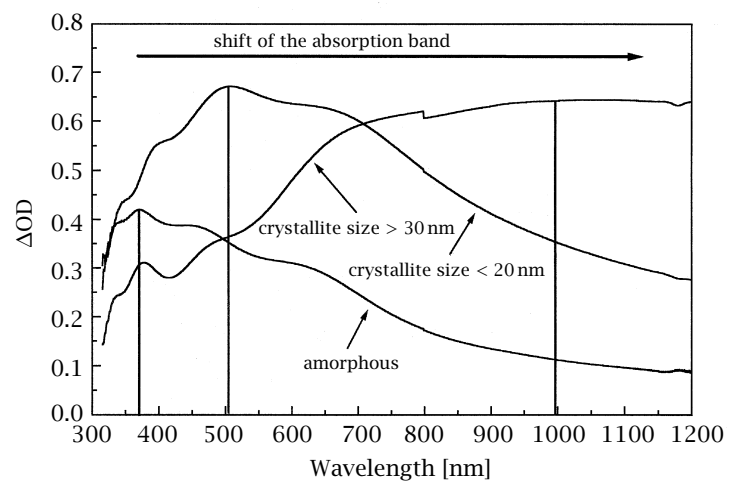

Figure 6. Typical optical spectra $\Delta \mathrm{OD}$ vs. $\lambda$ ) of pure and Ti doped niobia EC layers after $\mathrm{Li}^{+}$ions insertion. Well ordered layers with crystallite size $>30 \mathrm{~nm}$ show a blue color, weakly ordered layers with crystallite size $<25 \mathrm{~nm}$ show a gray color while all amorphous layer have a brown color $[17,18]$.

Layers sintered between 450 and $600{ }^{\circ} \mathrm{C}$ have been investigated up to 5000 cycles and, whatever the type and amount of doping and the sintering temperature, the EC properties have been found stable. The niobium oxide layers doped with $\mathrm{Sn}$ and $\mathrm{Zr}$ are still electrochromic but no improvement has been observed as the amount of $\mathrm{Li}^{+}$ions which can be inserted into the layer and consequently the change of the optical density decreased with increasing doping level. Nevertheless the coloration efficiency remains about the same at approx. $17 \mathrm{~cm}^{2} / \mathrm{C}$. As it was already observed [23], the incorporation of $\mathrm{Li}^{+}$improves the kinetics and the coloration efficiency increased to approx. $23 \mathrm{~cm}^{2} / \mathrm{C}$ up to a molar ratio $\mathrm{Li} / \mathrm{Nb}=0.1$ for the crystalline layers sintered between 500 and $600^{\circ} \mathrm{C}$. 
At $450{ }^{\circ} \mathrm{C}$ all the layers were amorphous and colored brown. At $500{ }^{\circ} \mathrm{C}$ only gray and brown colors have been found depending on the amount of doping while at $600{ }^{\circ} \mathrm{C}$ the colors were gray and blue. With Ti doping the coloration efficiency was also found to increase for crystalline layers (up to $27 \mathrm{~cm}^{2} / \mathrm{C}$ at $600{ }^{\circ} \mathrm{C}$ ). Amorphous layers coloring brown were found at $450{ }^{\circ} \mathrm{C}$ and up to $500^{\circ} \mathrm{C}$ for high doping ( $\left.\mathrm{Ti} / \mathrm{Nb}>0.3\right)$. At lower doping the layers colored blue for $T>500^{\circ} \mathrm{C}$. However, gray color was found for high doping at $600^{\circ} \mathrm{C}$.

The most interesting results were found for Mo doping. The pure (001) oriented hexagonal structure was already found at $450{ }^{\circ} \mathrm{C}$ for doping with 5 at $\%$ and up to $500{ }^{\circ} \mathrm{C}$ with 10 at $\%$ leading to a blue color. A pure weakly crystalline orthorhombic phase $\left(\mathrm{Nb}_{12} \mathrm{O}_{29}\right)$ with small crystallites $(15-20 \mathrm{~nm})$ was observed in films doped with 20 and 30 at $\%$ sintered at 450 and $500{ }^{\circ} \mathrm{C}$ leading to a gray color and a mixed structure with hexagonal $\mathrm{Nb}_{2} \mathrm{O}_{5}$ and orthorhombic $\mathrm{Nb}_{12} \mathrm{O}_{29}$ crystallite was observed with a 20 at\% Mo doping sintered at $450{ }^{\circ} \mathrm{C}$ and for all doped samples sintered at $600{ }^{\circ} \mathrm{C}$. A high doping (> 15 at\%) drastically favors an increase of the amount of $\mathrm{Li}^{+}$ions charge which can be incorporated into the layers and consequently a higher optical density change is observed.

Only two groups have reported the use of doped niobia as an EC electrode. Orel et al. [24, 25] have built solid state cells with the configuration glass/FTO/ $\mathrm{Li}_{x} \mathrm{Nb}_{2} \mathrm{O}_{5} /$ ormolyte/SnO 2 :Sb:Mo/FTO/glass. The molar ratio was $\mathrm{Li} / \mathrm{Nb}=0.1$ and the niobia layer was sintered at $500^{\circ} \mathrm{C}$. Such cells have been switched between $-4 \mathrm{~V}$ and $+2 \mathrm{~V}$ and exhibited a gray color in the colored state and transmission change up to $45 \%$ have been observed in the early cycles. Their lifetime was however short $(<500$ cycles $)$ due to the high negative potential used to obtain a coloration which is out of the range of the stability of the EC, IS and electrolyte layers. The second successful result has been obtained by Schmitt et al. $[18,26]$ who used the configuration glass//FTO/doped niobia/electrolyte(liquid)/ $\quad \mathrm{CeO}_{2}-\mathrm{TiO}_{2} / \mathrm{FTO} /$ glass. Applying the model developed by Bullock et al. [27], they show that, for this configuration, a reasonable coloration within the safe voltage range of $\pm 2.5 \mathrm{~V}$ could only be obtained with Mo doped niobia. The most important parameters necessary to simulate the coloration behavior of the cell are the Fermi potentials of both layers (Figure 7) which have been determined from coulometric titration curves by applying a current density of $5 \mu \mathrm{A} / \mathrm{cm}^{2}$. The Fermi potential increases significantly with the sintering temperature (shown here for pure $\mathrm{Nb}_{2} \mathrm{O}_{5}$ ). It remains similar for $\mathrm{Li}$ and Ti doped materials but decreases drastically for Mo doped niobia. Within the safe voltage range $( \pm 2.5 \mathrm{~V})$ required by the used electrolyte, all EC layers can

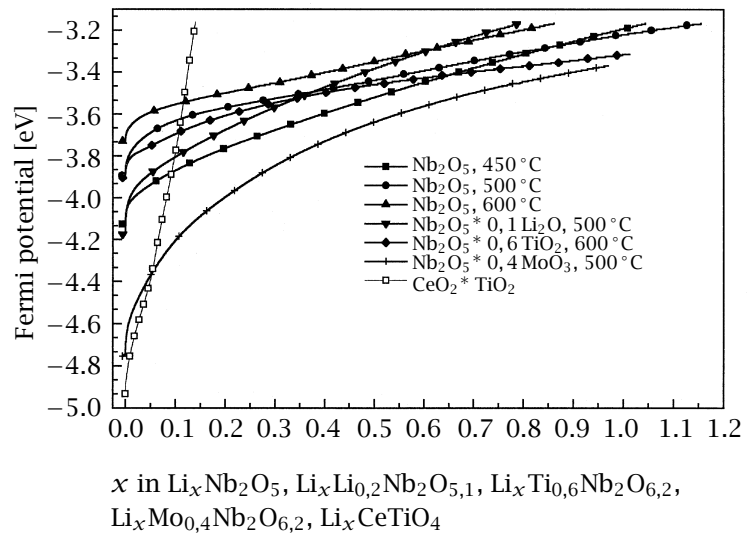

Figure 7. Fermi potential curves determined from coulometric titration after the $50^{\text {th }}$ chronoamperometric cycle for different pure and doped niobium oxides as well as for the ion storage layer $\mathrm{TiO}_{2}-\mathrm{CeO}_{2}[18,26]$.

incorporate a large amount of Li ions up to $x \cong 1$. The results are however quite different for the $\mathrm{CeO}_{2}-\mathrm{TiO}_{2}$ ion storage electrode and within the safe potential range only a small amount of Li up to $x \cong 0.14$ can be intercalated.

As the coloration efficiency for doped niobia is at most about $25 \mathrm{~cm}^{2} / \mathrm{C}$, a minimum amount of charge of approx. $40 \mathrm{mC}$ is necessary to obtain a change of the optical density of about 1 . According to the results discussed above this is readily realizable in an electrochemical cell with all niobia layers having a thickness of about $300 \mathrm{~nm}$. In a device this charge should be switched back and forth between the EC and IS electrodes. The model simulation shows that the best EC material is Mo doped niobia and that the thickness of the $\mathrm{CeO}_{2}-\mathrm{TiO}_{2}$ IS electrode should be typically 10 to 20 times thicker than that of the EC layer! This of course is technically not realizable. Cells made with smaller thickness will color but with a lower optical density variation. Figure 8 shows the change of light transmittance, $\Delta \tau$, calculated according to DIN EN410 (weighted with the light function $D_{65}$ and the human eye sensibility for day-light $V(\lambda)$ versus the number of cycles of $6 \times 8 \mathrm{~cm}^{2}$ devices made with a $180 \mathrm{~nm}$ thick $\mathrm{Nb}_{2} \mathrm{O}_{5} \bullet 0.4 \mathrm{Mo}$ EC electrode sintered at $600{ }^{\circ} \mathrm{C}$ and $\mathrm{a} \mathrm{TiO}_{2}-\mathrm{CeO}_{2}$ IS electrode made according to reference [30] with a thickness varying between $240 \mathrm{~nm}$ (1 layer) to approx. $950 \mathrm{~nm}$ (4 layers). A voltage of $\pm 2.5 \mathrm{~V}$ was applied during $120 \mathrm{~s}$ (each cycle).

The results obtained confirm only partially the simulation results. A thicker IS layer leads effectively to an increase in the transmission change but the response does not vary linearly. This is probably due to the fact that the ionic conductivity of these layers is low (which 


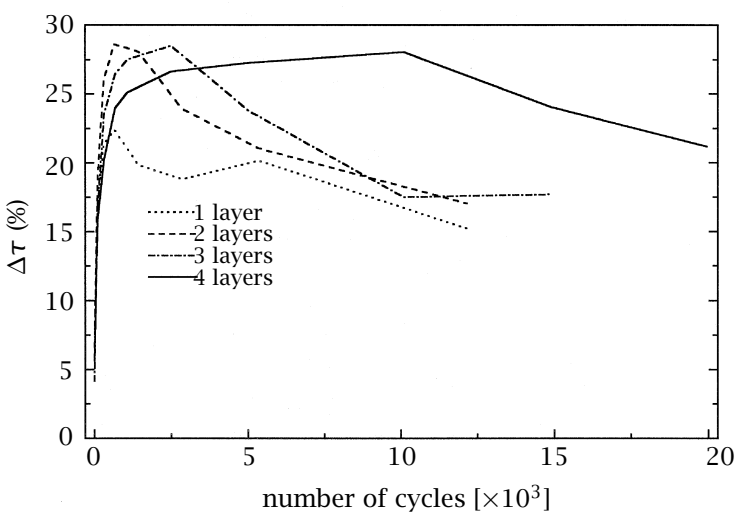

Figure 8. Change of light transmittance $\Delta t$ calculated according to DIN EN 410 (weighted with the relative light function $D_{65}$ and the human eye sensibility for day-light $V(\lambda))$ vs. the number of cycles of $6 \times 8 \mathrm{~cm}^{2}$ devices made with a $180 \mathrm{~nm}$ thick $\mathrm{Nb}_{2} \mathrm{O}_{5} \bullet 0.4 \mathrm{Mo}$ EC electrode and a $\mathrm{TiO}_{2}-\mathrm{CeO}_{2}$ IS electrode having a thickness varying between $240 \mathrm{~nm}$ (1 layer) to approx. $950 \mathrm{~nm}$ (4 layers). Applied voltage: $-2.5 \mathrm{~V}$; $+2.5 \mathrm{~V}$ each during $120 \mathrm{~s}[18,26]$.

is not taken into account by the model). In the early cycles the change of transmission is low but it strongly increases with the number of cycles, then passes by a maximum and decreases. It is believed that the deterioration of the cells is due to a corrosion effect between the electrolyte and the IS electrode. The highest amount of charge exchanged was $18 \mathrm{mC} / \mathrm{cm}^{2}$ obtained with 3 IS layers and the maximum change in transmission was $\Delta \tau=0.28$. The best cells were stable up to about 20000 cycles. These results however clearly show that a better IS electrode having a flatter Fermi potential variation and allowing a much higher $\mathrm{Li}^{+}$ions capacity should be developed in order to use niobium oxide as an EC material for the realization of EC devices.

\section{SOLAR CELLS}

Since the discovery by Graetzel [31, 32] that a dye sensitization of a porous coating of crystalline $\mathrm{TiO}_{2}$ nanoparticles could be used for the development of solar cells, many other wide-band gap semiconductors, including niobia, have been studied. Most of the cells tested till now consisted of a thick porous coating of crystalline nanoparticles, deposited on a transparent conducting glass substrate, and whose particles were coated with a chemically adsorbed monolayer of a Ru(II)-complex. The system is completed by an electrolyte with an iodide/triiodide redox mediator and a counter electrode comprising a catalyst. For $\mathrm{TiO}_{2}$ the overall conversion efficiency measured under $1000 \mathrm{~W} / \mathrm{m}^{2}$ solar simulator irradiation varies typically between 7 and
$12 \%$ with an open circuit photovoltage of 0.7 to $0.8 \mathrm{~V}$. As the conversion efficiency strongly depends on the surface area available to sensitize the semiconducting particles, the sol-gel process is therefore particularly adequate for the preparation of such porous coatings.

Several works have been reported with niobia coatings made by the sol-gel process [6]. Hu et al. [33] prepared niobia colloidal suspensions by hydrolyzing niobium alkoxide solutions $\left(\mathrm{Nb}(\mathrm{OEt})_{5}\right.$ dissolved in ethanol added to a triethylamine ethanolic aqueous solution and water) and autoclaving at $250{ }^{\circ} \mathrm{C}$. The films fired at $500{ }^{\circ} \mathrm{C}$ had the TT structure, were porous and presented a morphology consisting of needles. The authors only mention that a cell made with such a layer after coating with a $\mathrm{Ru}(\mathrm{II})$-complex gave a current conversion efficiency (IPCE) of $40 \%$ and an open circuit voltage of $0.4 \mathrm{~V}$, both values being much smaller than those obtained with $\mathrm{TiO}_{2}$. Wolf [34], using similar preparation techniques, showed that the specific BET area of the sintered materials was in the range of 30 to $50 \mathrm{~m}^{2} / \mathrm{g}$ and that the coatings had an IPCE of 33\% at $550 \mathrm{~nm} .0 .45 \mathrm{~cm}^{2}$ size cells presented an almost constant conversion efficiency of $2.5 \%$ under simulated solar light irradiation up to $100 \mathrm{~mW} / \mathrm{cm}^{2}$ ( 1 sun). The open circuit voltage, short circuit current and IPCE were found to decrease steadily by doping niobium oxide with Ta $\left(\mathrm{Nb}_{1-x} \mathrm{Ta}_{x}\right)_{2} \mathrm{O}_{5}$ up to $x=0.25$. Lenzman [35] prepared stable colloid solutions of $\mathrm{Nb}_{2} \mathrm{O}_{5}$ hydrolysis, an alkoxide solution, $\mathrm{Nb}(\mathrm{OEt})$ acac, in a solution of water, ethanol and DBV followed by an autoclaving process at $230{ }^{\circ} \mathrm{C}$ during $12 \mathrm{~h}$. A water based paste formulation prepared by adding hydroxypropyl cellulose allowed to realize up to $15 \mu \mathrm{m}$ thick, translucid $\mathrm{Nb}_{2} \mathrm{O}_{5}$ coatings by a tape casting process. After firing at $T>500{ }^{\circ} \mathrm{C}$, the coatings consisted of an agglomeration of about $20 \mu \mathrm{m}$ poorly defined particles, several of them having also large needle shape with a BET area of $55 \mathrm{~m}^{2} / \mathrm{g}$ at $600{ }^{\circ} \mathrm{C}$. Under $1000 \mathrm{~W} / \mathrm{m}^{2}$ solar irradiation, a $0.5 \mathrm{~cm}^{2}$ Ru-complex sensitized cell $15 \mu \mathrm{m}$ thick had an efficiency of $4 \%$, a fill factor of $69 \%, V_{\text {oc }}=595 \mathrm{mV}$ and $I_{\mathrm{SC}}=9.7 \mathrm{~mA} / \mathrm{cm}^{2}$. The current response was found linear between 10 and $100 \mathrm{~mW} / \mathrm{cm}^{2}$ solar light irradiation.

Sayama et al. [36] prepared $1 \mathrm{~cm}^{2}$ dye sensitized cells where a 6 to $8 \mu \mathrm{m}$ thick niobia electrode was made by spreading a slurry of either commercial powders or powders made by calcining niobium hydroxide between 300 and $900{ }^{\circ} \mathrm{C}$. The coatings were porous and appear as an agglomeration of $100-200 \mathrm{~nm}$ size particles. However, the overall photoelectrochemical results were not good. An improvement was obtained by dropping niobium alkoxide on $700{ }^{\circ} \mathrm{C}$ sintered coatings (made from $\mathrm{Nb}$ hydroxide) and then calcining the system again at $500{ }^{\circ} \mathrm{C}$. The surface of the particles became rougher and thus allowed to increase the amount of dye adsorbed on 
the surface by a factor of 1.2 resulting in an increase of the photoconductivity between the particles. Nevertheless the overall solar-to electric conversion efficiency remained low, typically 2\% under AM1.5 $\left(1000 \mathrm{~W} / \mathrm{m}^{2}\right)$ irradiation.

The results of the author's group have been obtained by spin depositing on FTO coated glass partially hydrolyzed ethanolic niobia sols submitted to an ultrasonic treatment and then boiled under reflux [37, 38]. The BET surface of any of the coatings were found to increase with the sintering temperature up to a maximum of $26 \mathrm{~m}^{2} / \mathrm{g}\left(500^{\circ} \mathrm{C}\right)$ and then to strongly decrease down to $13 \mathrm{~m}^{2} / \mathrm{g}$ at $650{ }^{\circ} \mathrm{C}$. The maximum amount of dye which could be adsorbed on a $10 \mu \mathrm{m}$ thick layer was $3.3 \cdot 10^{-8} \mathrm{~mol} / \mathrm{cm}^{2}$. The current response of $0.2 \mathrm{~cm}^{2} \mathrm{so}-$ lar cell realized with such coatings was not linear with the solar irradiation intensity and the solar-to-electric corrosion decrease from about $4.9 \%\left(I<100 \mathrm{~W} / \mathrm{m}^{2}\right)$ to $2 \%\left(I=1000 \mathrm{~W} / \mathrm{m}^{2}\right)$.

A modification of the morphology of the films was obtained by adding to the sol a polymeric ligand and carbon soot [39]. The deposited nanoscopically phaseseparated film allows to obtain extra micropores during the burn-out of the organic products. Although the average porosity (about $45 \%$ ) and the BJH pore size diameter $(9 \mathrm{~nm})$ did not change, the BET surface area, the amount of dye adsorbed and the roughness factor were all effectively increased to about $45 \mathrm{~m}^{2} / \mathrm{g}$, $8.8 \cdot 10^{-8} \mathrm{~mol} / \mathrm{cm}^{2}$ and $530,(10 \mu \mathrm{m}$ thick layer $)$ respectively after a sintering at $520^{\circ} \mathrm{C}$.

Some results of the ICPE of the layers is shown in Figure 9 and 10. The layers were sensitized by a $\mathrm{Ru}$ (II)-complex and the electrolyte was a mixture of $80 \%$ propylene carbonate (PC) and 20\% acetonitrile (ACN) containing $\mathrm{I}^{-} / \mathrm{I}_{3}^{-}$as a redox mediator. Figure 9 shows that the IPCE of a $10 \mu \mathrm{m}$ thick layer increases with the sintering temperature up to maximum value of about $51 \%\left(600^{\circ} \mathrm{C}\right)$. For this temperature, the IPCE was also found to increase with the thickness of the layer, saturating for a value of about $16 \mu \mathrm{m}$ (Figure 10). Moreover, Figure 11 shows that the spectral shape of IPCE obtained with a $\mathrm{TiO}_{2}$ coating (from INAP, Gelsenkirchen) and $\mathrm{Nb}_{2} \mathrm{O}_{5}$ measured under the same conditions are practically identical.

$\mathrm{Nb}_{2} \mathrm{O}_{5}$ solar cells with an area of $4 \mathrm{~cm}^{2}$ have been realized. Figure 12 shows their configuration. Their electrical characterization has been measured by irradiating a spot of $1 \mathrm{~cm}^{2}$ from a AM $1.5 \mathrm{G}$ solar light simulator (Oriel, SP81160-1452) whose intensity was varied up to $1000 \mathrm{~W} / \mathrm{m}^{2}$. Figure 13 shows typical I-V curves obtained for different solar light irradiation. A summary of the data as well as a comparison of the electric characterization with $\mathrm{Nb}_{2} \mathrm{O}_{5}$-solar cells made in other laboratories (EPFL [34, 35] and NIM [36]) and of a $0.4 \mathrm{~cm}^{2} \mathrm{TiO}_{2}$ cell [40] is shown in the Figure 14.

All the $\mathrm{Nb}_{2} \mathrm{O}_{5}$ and $\mathrm{TiO}_{2}$ cells exhibit a linear behavior of the short circuit current with the light

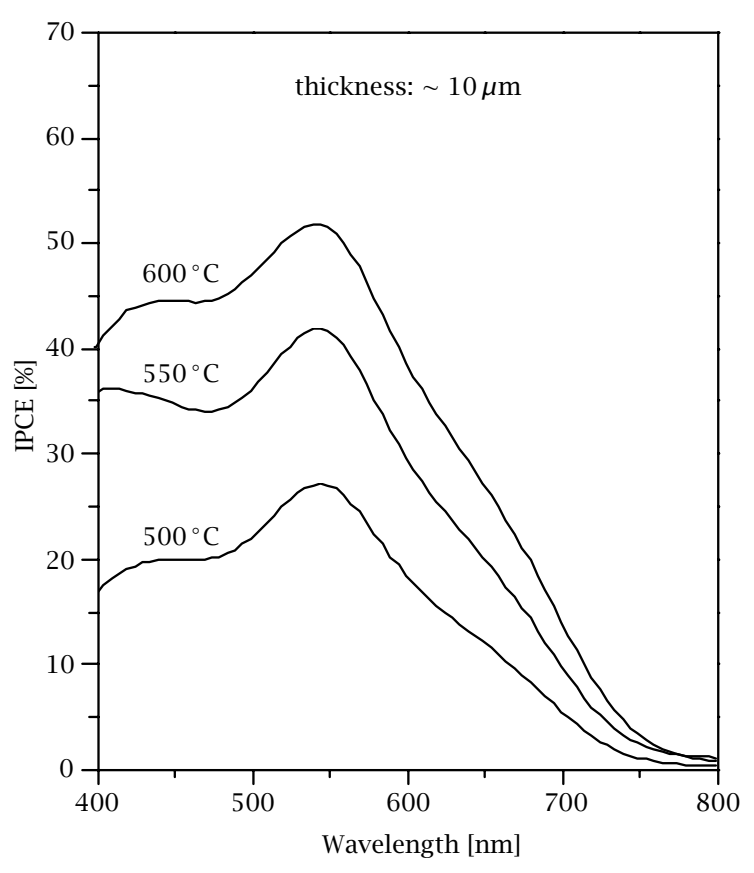

Figure 9. Variation of the IPCE of a $\mathrm{Nb}_{2} \mathrm{O}_{5}-P E G(M W=$ $20000)+C$ soot layer with the sintering temperature. The thickness of the layers is about $10 \mu \mathrm{m}$.

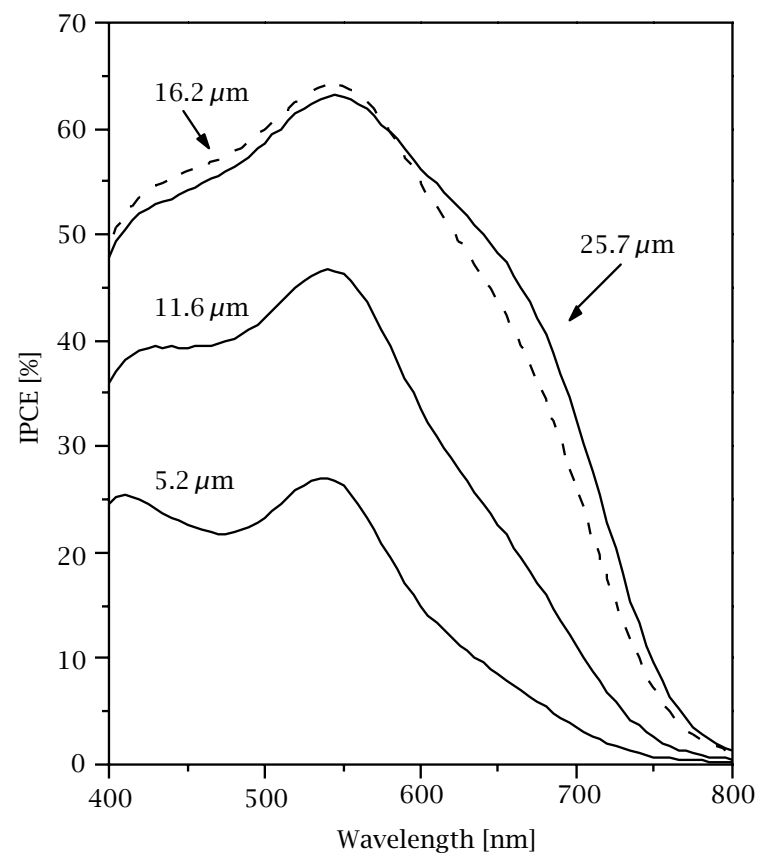

Figure 10. Variation of the IPCE of $\mathrm{Nb}_{2} \mathrm{O}_{5}-P E G(M W=$ $20000)+C$ soot layers sintered at $600^{\circ} \mathrm{C}$ with their thickness.

intensity (Figure 14(b)). Under 1 sun irradiation, our cell has a value of $12.2 \mathrm{~mA} / \mathrm{cm}^{2}$, higher than those made 


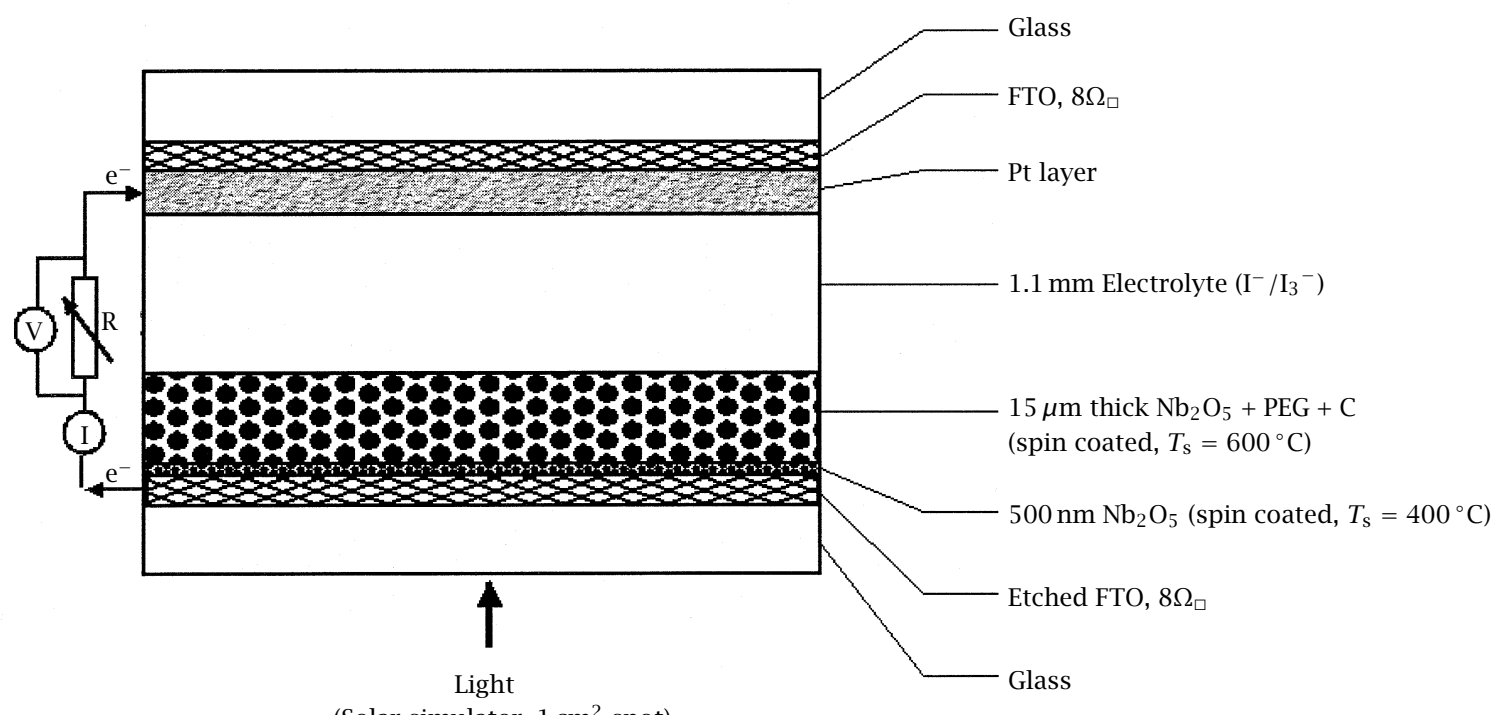

(Solar simulator, $1 \mathrm{~cm}^{2}$ spot)

Figure 12. Configuration of a $4 \mathrm{~cm}^{2}$ area $\mathrm{Nb}_{2} \mathrm{O}_{5}$ solar cell.

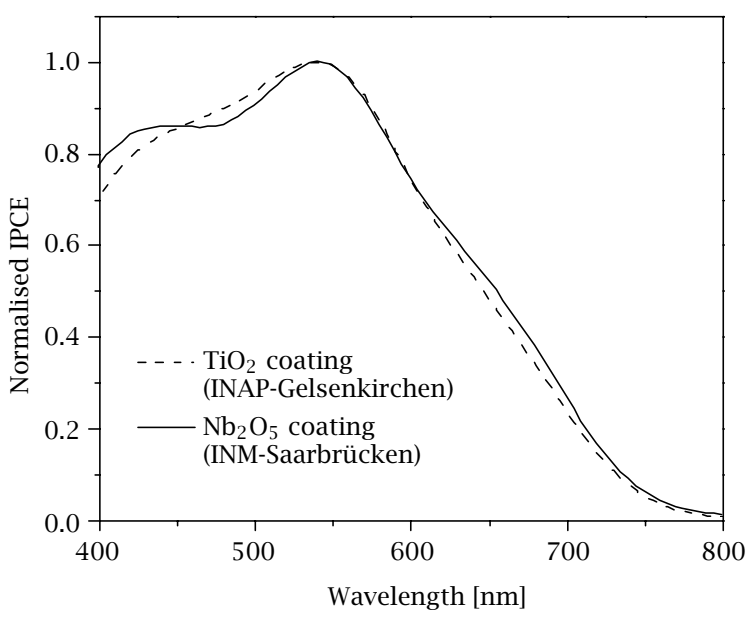

Figure 11. Comparison of IPCE normalized spectrum of sensitized $\mathrm{TiO}_{2}$ and $\mathrm{Nb}_{2} \mathrm{O}_{5}$.

at EPFL and NIM. The open circuit potential slightly increases with the light intensity from about 0.60 to $0.665 \mathrm{~V}$ and is also slightly higher than the other one (Figure 14(c)). However as can be seen from the shape of the I-V curves, a strong decrease of the fill factor from about 0.72 down to 0.48 is observed in our cell and the value under 1 sun is smaller than those reported at EPFL and NIM (Figure 14(d)). This strong decrease drastically affects the solar-to-electric conversion (Figure 14(a)) which decreases from about $7 \%\left(100 \mathrm{~W} / \mathrm{m}^{2}\right)$ down to $4.0 \%$ under $1000 \mathrm{~W} / \mathrm{m}^{2}$, a value also achieved

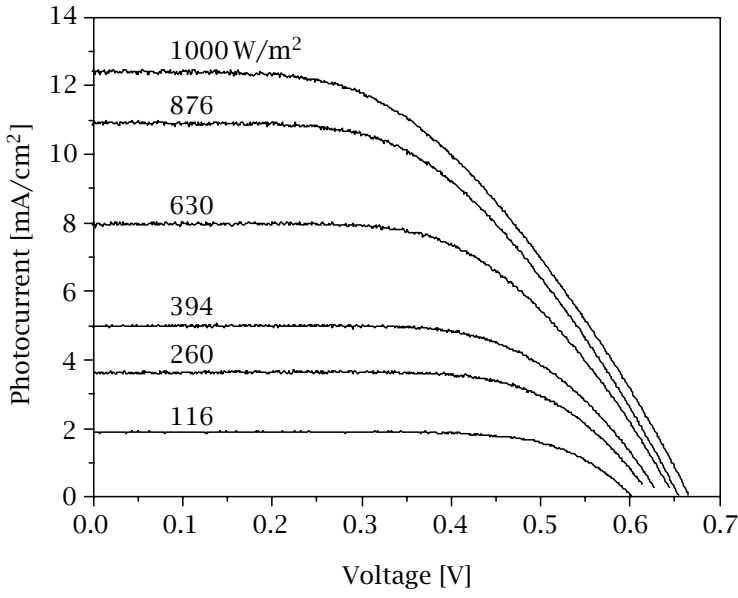

Figure 13. Typical I-V curves obtained with a $4 \mathrm{~cm}^{2} \mathrm{Nb}_{2} \mathrm{O}_{5}$ solar cell.

at EPFL [35]. The overall values of $\eta$ are also lower than those obtained with cells made with sensitized $\mathrm{TiO}_{2}$ nanocrystalline cells [40].

The results so far obtained by us for $\mathrm{Nb}_{2} \mathrm{O}_{5}$-solar cells are nevertheless quite promising. At low solar irradiation, the efficiency of a large $4 \mathrm{~cm}^{2} \mathrm{Nb}_{2} \mathrm{O}_{5}$ cell is already $70 \%$ of that obtained with a $0.4 \mathrm{~cm}^{2} \mathrm{TiO}_{2}$ cell [40]. It is believed that improvement can be obtained by designing a better configuration in particular by reducing the size of the cell and also the thickness of the electrolyte. 

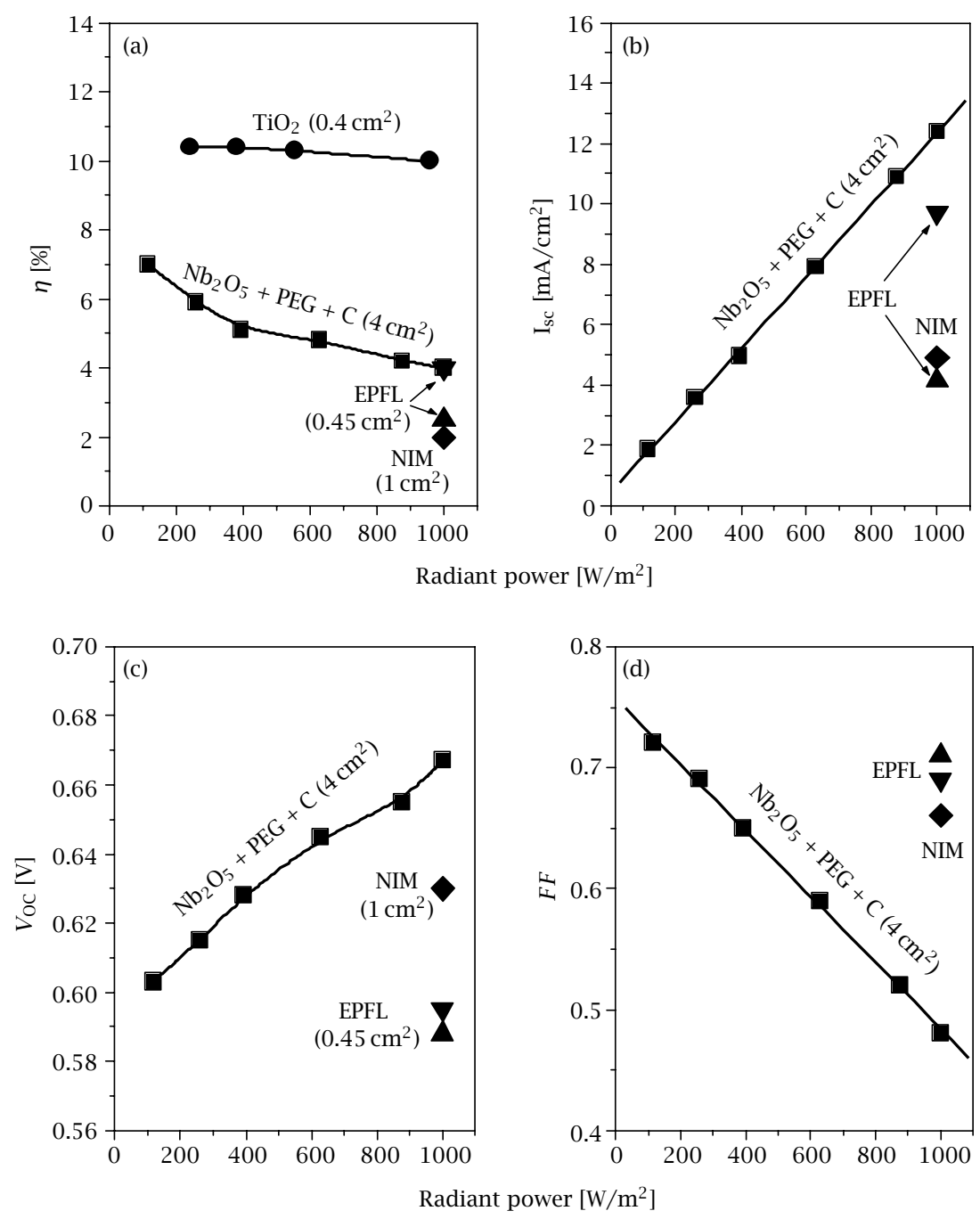

Figure 14. Comparison of the electrical characterization of $\mathrm{Nb}_{2} \mathrm{O}_{5}$ solar cells made in different laboratories (INM (- $\left.\mathbf{m}\right)$, EPFL $\Delta$ [34], $\mathbf{v}$ [35], and NIM $\bullet$ [36] and $\mathrm{TiO}_{2} \bullet$ [40]. Note that the configuration, areas, electrolyte and dye are different for each cell (a) solar-to-electrical conversion $\eta(\%)(b)$ short circuit current $I_{\mathrm{SC}}\left(\mathrm{mA} / \mathrm{cm}^{2}\right)$ (c) open circuit voltage $V_{\mathrm{OC}}(V)(d)$ fill factor FF.

\section{CONCLUSION}

This paper has briefly summarized the state of the art achieved with pure or doped niobium pentoxide made by sol-gel processes in the field of electrochromism and nanocrystalline solar cells. Since its first preparation in 1986, many laboratory developments have been done for the use of this material either in the form of thin or thick coatings, powders, xerogels or aerogels. Pure and doped niobium oxide coatings exhibit quite good and stable properties for the intercalation of $\mathrm{H}^{+}$and $\mathrm{Li}^{+}$ions and are promising compounds for the development of electrochromic devices. 100 to $300 \mathrm{~nm}$ thick layers can be used reversibly either as EC or IS electrodes with a lifetime higher than $10^{4}$ cycles. Depending of the type of doping and the sintering temperature the color of the layers seen in transmission may be brown, gray or blue. Their use in such devices is however dependent on the discovery of an adequate counter electrode. As niobium oxide has quite similar semiconducting properties as $\mathrm{TiO}_{2}$ its use in the form of thick porous coatings for the development of nanocrystalline solar cells has also been demonstrated. The 7\% solar-to-electric conversion obtained at low light intensity illumination $\left(<100 \mathrm{~W} / \mathrm{m}^{2}\right)$ is already $70 \%$ of that obtained with titania. Such coatings are therefore quite promising but a development is still needed to increase the efficiency at all illumination level.

\section{ACKNOWLEDGEMENT}

The authors thank the Federal Ministry for Education, 
Research and Technology of Germany and the State of Saarland (Germany) for their financial support.

\section{References}

[1] Gmelins Handbuch der Anorganischen Chemie, Niob und Sauerstoff, Vol. B1, Verlag Chemie GmbH, Weinheim/Bergstrasse, 1970, pp. 49-79.

[2] J. Eckert, Niobium and Niobium compounds, in Ullman's Encyclopedia of Industrial Chemistry, $5^{\text {th }}$ edition, Vol. A17, 1990, pp. 251-264.

[3] G. Brauer, Zeitschrift für anorganische und allgemeine Chemie 248(1) (1941), 1.

[4] H. Schäfer, R. Gruehn, and F. Schulte, Angew. Chem. 78(1) (1966), 28.

[5] I. Ko and J. G. Weissman, Catalysis Today 8 (1990), 27.

[6] M. A. Aegerter, Solar Energy Materials \& Solar Cells 68 (2001), 401.

[7] Agrawal, J. P. Cronin, and R. Zhang, Solar Energy and Solar Cells 31 (1993), 9.

[8] M. A. Aegerter, Proc. Int. Congress on Glass, Beijing 1 (1995), 95.

[9] M. A. Aegerter, Sol-gel Chromogenic Materials and Devices, in Structure and Bonding: Optical and Electronic Phenomena in Sol-Gel Glasses and Modern Applications, R. Reisfeld and C. Jorgensen (eds.), Vol. 85, Springer-Verlag, Berlin, Heidelberg, 1996, pp. 149-194.

[10] M. A. Aegerter, C. O. Avellaneda, A. Pawlicka, and M. Atik, J. Sol-gel Science and Technology 8 (1997), 689.

[11] B. Reichman and A. J. Bard, Journal of the Electrochemical Society 127 (1980), 241.

[12] B. Reichman and A. J. Bard, Journal of the Electrochemical Society 128 (1981), 344.

[13] T. Maruyama and T. Kanagawa, J. Electrochem. Soc. 141 (1994), 2868.

[14] K. Yoshimura, T. Miki, S. Iwama, and S. Tanemura, Jpn. J. Appl. Phys. 34 (1995), L1293.

[15] G. R. Lee and J. A. Crayston, J. Mater. Chem. 6 (1996), 187.

[16] G. R. Lee and J. A. Crayston, J. Mater. Chem. 4 (7) (1994), 1093.

[17] Schmitt and M. A. Aegerter, Switchable Materials and Flat Displays, C. M. Lampert (ed.), Vol. 3788, SPIE, Bellingham, Washington, USA, 1999, pp 93102.

[18] M. Schmitt, PhD Thesis, Institut für Neue Materialien, INM and Universität des Saarlandes, Saarbrücken, Germany, 2000.

[19] A. J. Bard and L. R. Faulkner, Electrochemical Methods, Fundamentals and Applications, John Wiley \& Sons, Inc., New York, 1980.
[20] B. Ohtani, K. Iwai, S.-I. Nishimoto, and T. Inui, Journal of the Electrochemical Society 141 (1994), 2439.

[21] S. Cramer v. Clausbruch, PhD Thesis, Institut für Neue Materialien, INM and Universität des Saarlandes, Saarbrücken, Germany, 2000.

[22] C. O. Avellaneda, PhD Thesis, University of Sao Paulo, Brazil, 1999.

[23] M. Macek, B. Orel, and U. Opara Krasovec, J. of the Electrochemical Society 144 (1997), 3002.

[24] M. Macek and B. Orel, Solar Energy Mater. Solar Cells 54 (1998), 121.

[25] B. Orel, U. Opara Krasovec, M. Macek, F. Svegl, and U. Lavrencic Stangar, Solar Energy Materials \& Solar Cells 56 (1999), 343.

[26] M. Schmitt and M. A. Aegerter, Switchable Materials and Flat Displays, C. M. Lampert (ed.), Vol. 3788, SPIE, Bellingham, Washington, USA, 1999, pp. 75-83.

[27] N. Bullock and H. M. Branz, Optical Materials Technology for Energy Efficiency and Solar Energy Conversion XIV, Vol. 2531, SPIE, Bellingham, Washington, USA, 1995, pp. 152-160.

[28] O. F. Schirmer, V. Wittwer, and G. Brandt, Journal of the Electrochemical Society 124 (1977), 749.

[29] V. Wittwer, O. F. Schirmer, and P. Schlotter, Solid State Communications 25 (1978), 977.

[30] B. Munro, P. Conrad, S. Krämer, H. Schmidt, and P. Zapp, Solar Energy Materials and Solar Cells 54 (1998), 131.

[31] B. O’Reagan and M. Graetzel, Nature 343 (1991), 737.

[32] M. Graetzel, MRS Bull. XVIII (1993), 61.

[33] L. Hu, M. Wolf, M. Graetzel, and Z. Jiang, J. Sol-gel Science and Technology 5 (1995), 219.

[34] M. Wolf, PhD Thesis, Ecole Polytechnique Fédérale de Lausanne, Switzerland, 1998.

[35] F. Lenzmann, PhD Thesis, Ecole Polytechnique Fédérale de Lausanne, Switzerland, 2000.

[36] K. Sayama, H. Sugihara, and H. Arakawa, Chem. Mater. 10 (1998), 3825.

[37] Y. Guo, S. Heusing, and M. A. Aegerter, Innovative Material in Advanced Energy Technologies, Vol. 24, Adv. Sci. Technol. (Faenza, Italy), 1999, pp. 585595.

[38] Y. Guo and M. A. Aegerter, Thin Solid Films 351 (1999), 290.

[39] Y. Guo and M. A. Aegerter, Functional Materials, Vol. 13, EUROMAT 99, 2000, p. 250.

[40] M. K. Nazeeruddin, A. Kay, I. Rodicio, R. HumphryBaker, E. Müller, P. Liska, N. Vlachopoulos, and M. Graetzel, J. Am. Chem. Soc. 115 (1993), 6382. 


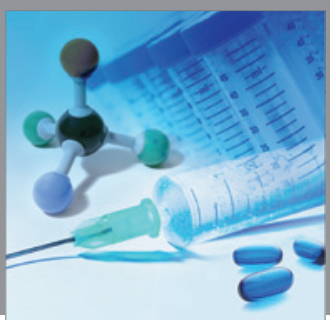

International Journal of

Medicinal Chemistry

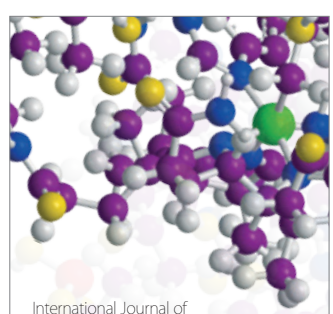

Carbohydrate Chemistry

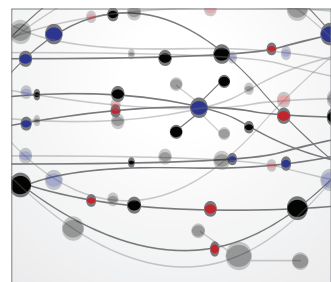

The Scientific World Journal
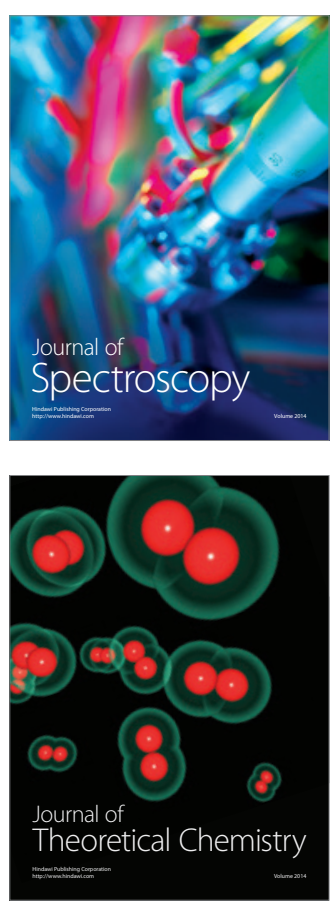
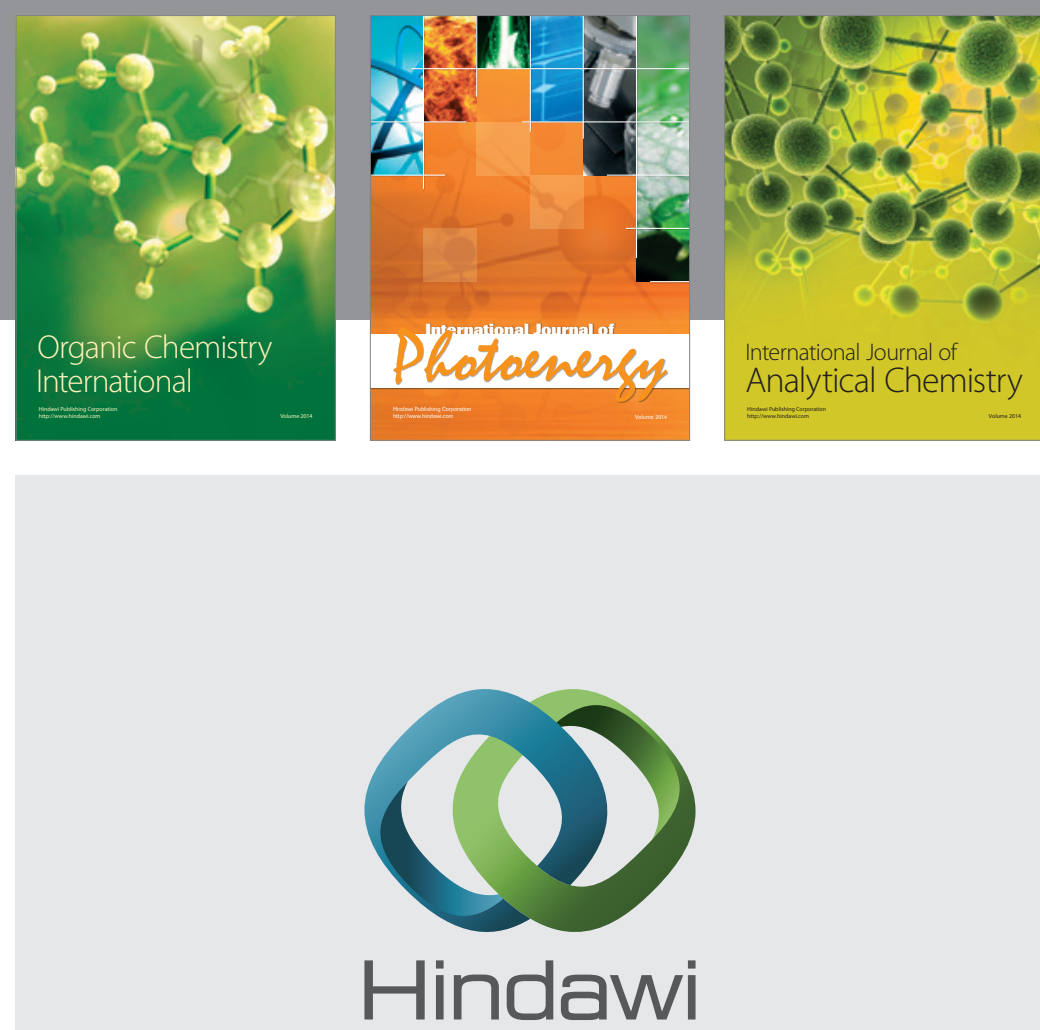

Submit your manuscripts at

http://www.hindawi.com
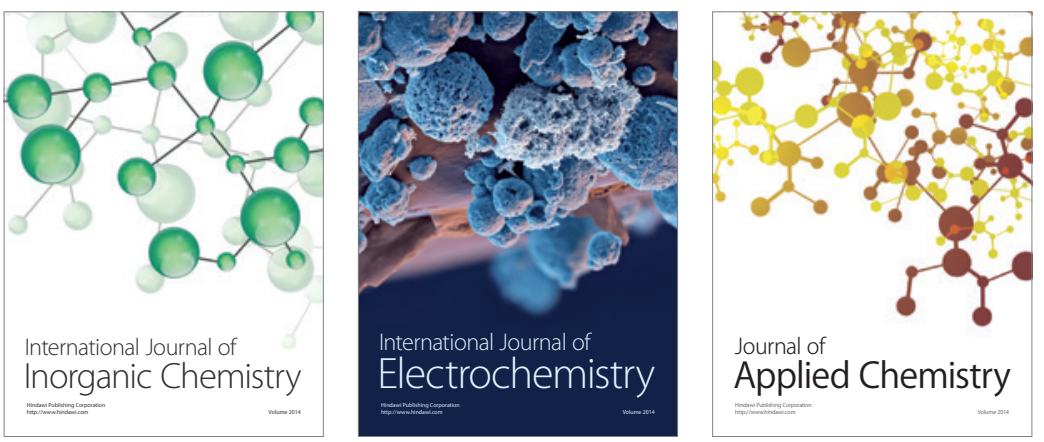

Journal of

Applied Chemistry
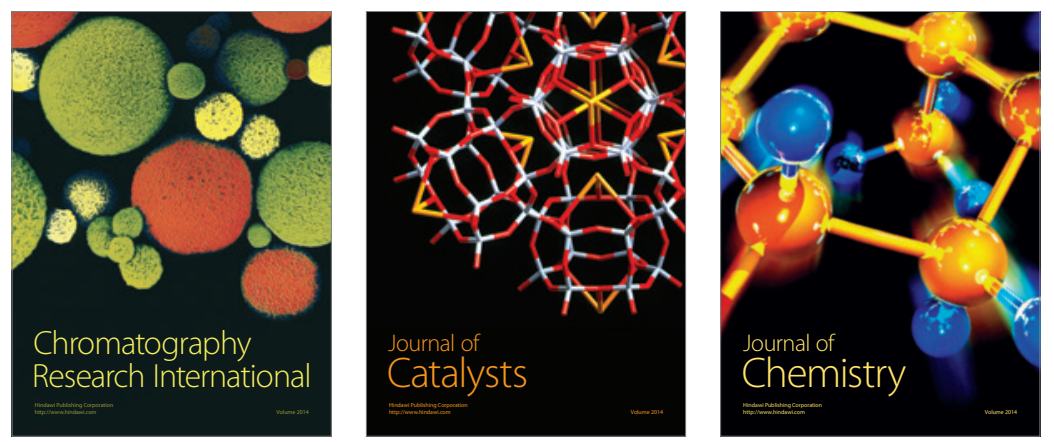
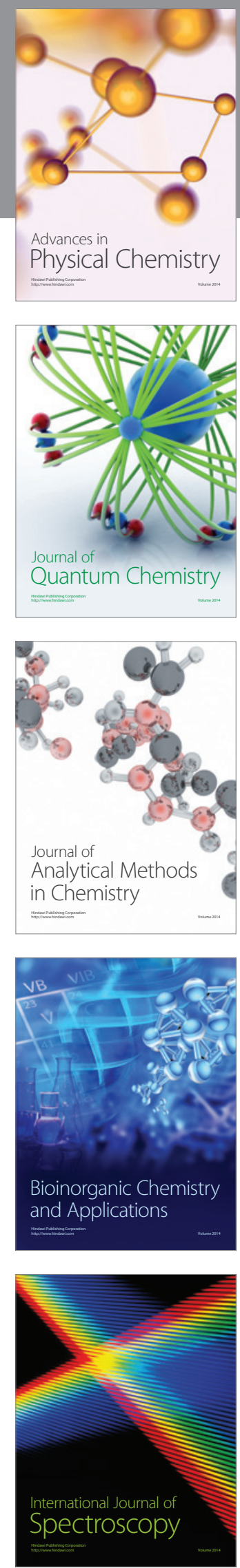